ESTUDIOS SOBRE EL NORTE DE ÁFRICA, IBEROAMÉRICA Y FILIPINAS 


\title{
LOS SERVICIOS DEL CAPITÁN MIGUEL DE PEREA EN LA ARMADA DE GUARDA DE LA FLOTA DE INDIAS
}

\author{
Juan Corbalán de Celis y Durán \\ Académico Correspondiente \\ de la RAC Valenciana
}

Resumen: El capitán Miguel de Perea, soldado que se moverá en el arte de la guerra entre los conocimientos de la Edad Media y el Renacimiento, será capaz de emplearse en los distintos ramos de la milicia, siendo un militar reconocido en su tiempo por dos hechos de cierta importancia que protagonizó en su carrera militar, la toma del estandarte real en la batalla de Noáin, y la captura de una nao del rey de Francia. Hoy se le recuerda sobre todo por sus trabajos como ingeniero en las defensas de Melilla. Tras una breve semblanza del personaje, nos adentramos en sus servicios en la armada de guarda, detallando su viaje a Canarias y la toma de dicha nao, deshaciendo el error de la noticia recogida sobre su enfrentamiento a una numerosa escuadra francesa, y terminamos con una reseña sobre su estancia y fallecimiento en Melilla.

Palabras clave: Miguel de Perea, Ingeniero militar, Armada de guarda, Melilla.

Abstract: Captain Miguel de Perea, army man who navigate in the art of war between the knowledge and skills of the middle Ages and the Renaissance. Was proficient in all the different branches of the army, being valued because of two fairly important facts that he achieved during his carrier. The capturing of the Royal banner at the battle of Noáin and the capture of one caravel owned by the King of France. Today is remembered mainly because of his work as an engineer on Melilla fortifications. After a short biographical sketch of the figure, we enter in detail of his service at the guard fleet, detailing his trip to the Canary Island and the capturing of the caravel, clarifying the errors on the news saying about confronting a large French fleet. Concluding with a review about his time and decease in Melilla.

Keywords: Miguel de Perea, Military engineer, Guard fleet, Melilla

\section{Introducción}

El malagueño Miguel de Perea, nacido en las postrimerías del siglo XV, como hombre de su época y en contacto con la Italia renacentista, se formará 
como artillero e ingeniero dentro de la escuela española de transición, sabiendo adaptar los viejos modelos de la Edad Media a las nuevas técnicas de fortificar ${ }^{1}$, desempeñando distintas funciones en su dilatada carrera dedicada al servicio de las armas, adquiriendo una reputación importante, que le acreditará como valiente soldado y capitán entendido. En la documentación aparecerá nombrado como capitán de infantería, capitán de trincheras, y capitán de artillería, adquiriendo en estos últimos empleos los conocimientos y experiencias necesarios para poder emplearlos en las obras de fortificación que se le encargarán. También desempeñará durante algunos años labores de "general de armada" mandado algunas de esas pequeñas escuadras que se organizaban para protección de la flota de Indias.

Las primeras noticias impresas que tenemos de Miguel de Perea son las que en 1634 recogía Sandoval en la primera parte ${ }^{2}$ de su historia de Carlos V, en la que narra la batalla que el Emperador dio a los franceses el domingo 30 de junio de 1521, y decía:

"Venía en el campo Español Miguel de Perea, cavallero, noble, natural de Málaga, moço de poca edad, si bien de fuerças y esfuerço señalado, hizo una hajaña notable con que se dio fin a esta jornada y se concluyó la victoria: y fue por el esquadrón donde estava el estandarte Real de Francia, llegó él peleando, y mató al que lo tenía, sacándoselo de las manos, y lo ganó y defendió, sin poder los Franceses cobrarlo, y assí el Emperador le dio privilegio para que lo pusiesse en el escudo de sus armas.....Y así, passó esta memorable batalla Domingo último día de Junio del dicho año de 1521”.

En la segunda parte ${ }^{3}$, publicada años más tarde en Amberes, en 1681, se repiten estas noticias de la edición anterior, y se añade una semblanza de Miguel de Perea:

${ }^{1}$ BRAVO NIETO, Antonio. "Miguel de Perea” En Diccionario Biográfico Español, Real Academia de la Historia, Madrid, 2009, p.656.

2 SANDOVAL, Prudencio de. Historia de la vida y hechos del Emperador Carlos V. Primera parte. Pamplona, 1634, p. 507.

${ }^{3}$ SANDOVAL, Prudencio de. Historia de la vida y hechos del Emperador Carlos V. Segunda parte. Amberes 1681, p.362. 
“Servía al Emperador en estas guerras el capitán Miguel de Perea, cavallero noble, descendiente por línea recta de Rodrigo de Perea, Adelantado de Cazorla y Camarero del Rey don Enrique III. El cual Capitán era tan valeroso y exercitado en las armas, que siendo de poca edad, en la batalla que los Castillanos dieron a los Franceses en la cuenca de Pamplona año 1522 (como dexo dicho en el libro 10 desta historia) quitó el estandarte Real que traya el General Francés, y lo ganó ${ }^{4}$, y por tan señalado servicio le hizo merced el Emperador, y dio cedula con palabras de mucho encarecimiento y estima, para que lo pusiese en el escudo de sus armas, en el dicho año de $1522^{5}$, y le hizo contino de su casa, que antes que se mudasen el servicio de la casa de castilla era de los oficios más honrados de la casa Real. Año 1537 por el mes de Setiembre, estando el Emperador en Monzón, rezelándose de que en Francia se hazía una gruesa armada de treze navíos con tres mil hombres de pelea con intención de yr a robar las costas de las Indias, no se fiando de la armada con que havía ydo Blasco Núñez Vela, mandó el Emperador que quatro navíos que andavan guardando el mar de Andalucía se armasen muy bien, y que Miguel de Perea fuesse por General dellos, y procurasse juntar con Blasco Núñez para que con más seguridad traxessen a España el oro y plata de las Indias. Hallose antes desto Miguel de Perea en la batalla de Pavía, y en la jornada de Viena contra el Turco, y después destos tiempos en las guerras de Alemaña. Fue Capitán e un gran soldado. Estava a cuenta deste capitán el lugar y fuerza de Cariñán, y con los Españoles que tenía resistía valerosamente al enemigo, pero como era poderoso no bastavan sus fuerzas, y los Italianos que dentro estavan no querían pelear como debían, por el odio, emulación y envidia que de los Españoles tenían, pareciéndoles que el

${ }^{4}$ Este hecho por el que se recuerda a Miguel Perea, sería recogido posteriormente en distintas historias generales, como la de: MARIANA, Juan. Continuación de la Historia de España. Tomo I y XII. Amberes, 1766, p.152, y la de FERRERAS, Juan. Synopsis historia chronologica de España Parte 13, Madrid, 1775, p.302.

${ }^{5}$ El año fue el de 1521, como señalaba anteriormente. Poco después de la batalla, el 18 de julio de 1521 el capitán Miguel de Perea mandaba hacer declaración testifical de los hechos para que quedase constancia de los mismos. FERNÁNDEZ MARTín, Luis. "En torno a la batalla de Noáin”, Príncipe deViana. $\mathrm{n}^{\circ}$ 40, Pamplona. 1979, p. 376. 
Capitán que tenían lo era, y que se hazían los Españoles dueños de todo, como suele hazer esta nación por ser de suyo altivos y de bravos coraçones. Sabiendo el Marqués del Vasto la poca conformidad que en Cariñán avía, y que los Italianos descontentos por no tener Capitán de su nación, peleavan mal, determinó quitar de allí al Capitán Miguel de Perea, si bien estava seguro que por él no se perdería, y savía quanto se avía mostrado allí resistiendo al enemigo, como el Emperador lo escrivió después dándose por muy bien servido de él. Puso el Marqués en Cariñan en lugar de Miguel de Perea a Pyrro Colona singular Capitán Italiano con setecientos Españoles y otros tantos Italianos y Tudescos, del qual luego diremos".

Este sonado hecho de armas contra las tropas francesas ocurrido en la cuenca de Pamplona, cerca de Noáin, recordado por la exitosa y sonada acción de arrebatar el estandarte real de Francisco I al Alférez que lo portaba, y de haber quedado prisionero el general que los mandaba, el señor de Asparrós, significaría para Miguel Perea el inicio de su promoción dentro de su trayectoria como militar.

Aunque Sandoval nos dice que en esos momentos Perea era un mozo de poca edad, el hecho que ya fuese capitán, patente que se recomendaba no dar a persona que no hubiese alcanzado la edad suficiente en la que ya se había adquirido la cordura y prudencia necesaria para poder mandar sin acciones temerarias a sus soldados, junto con las expresiones con que se dirige a sus hombres durante la batalla, a los que llama hijos -"hijo mío, Gámez, llegaos acá" - nos hace pensar que quizá no fuese tan mozo, y que en esos años ya hubiese alcanzado seguramente la cuarentena ${ }^{6}$.

Expulsados los franceses de Navarra tras la batalla de Noáin, se acometen seguidamente las obras de mejoras de las fortificaciones de la ciudadela de Pamplona, en las que van a intervenir, entre otros, dos de los ingenieros italianos que el emperador tiene a su servicio, hacia 1526 Gabriel Tadino de Martinengo, y algo más tarde en 1534-1538, Benedicto de Rávena, personajes cuya andadura profesional será coincidente en lugares y tiempos con Miguel de Perea.

Pasados a penas cuatro años de estos sucesos, Perea pasa a Italia for- 
mando parte del ejército que a las órdenes del marqués de Pescara invade la Lombardía. Participa en la batalla dada a los franceses en febrero de 1525 para levantar el sitio de Pavía, donde es derrotado su ejercito y hecho prisionero su monarca Francisco I. Hombre al parecer diestro en las armas y con buenas habilidades aparte, durante sus años en Italia, va a perfeccionar sus conocimientos como artillero, práctica en la que se inició al menos desde 1500, y así, trascurridos dos años de estancia en Italia, el primero de agosto de 1525, "acatando su habilidad y fidelidad" a la corona, se le nombraba maestro de trincheras de artillería ${ }^{7}$, y al año siguiente Gabriel Tadino, que había sido nombrado por CarlosV general de la artillería y se encontraba en Pamplona, lo nombraba su teniente en el reino de Navarra. Esta práctica como artillero, le facilitará el poder desarrollar mejor el nuevo arte de la fortificación, nacido sobre todo como oposición al empleo de la artillería de sitio. El conocimiento de las piezas de artillería y de sus efectos le ayudará a desarrollar las construcciones que esas mismas piezas iban a tratar de destruir, lo que unido a las experiencias adquiridas durante los distintos sitios en que participó, de los que al menos sabemos que estuvo dirigiendo, esta vez como sitiado, la defensa de la plaza de Cariñano ${ }^{8}$, le llevarán a adquirir formación como ingeniero militar, al menos en cuanto a la traza y mejor disposición de las defensas.

A primeros de julio de 1527 era nombrado teniente de la capitanía de Vasco de Acuña ${ }^{9}$ y marcharía nuevamente a Italia para proseguir la guerra

${ }^{6}$ La primera referencia documental de Miquel de Perea como militar es de 1500, fecha que parece confirmarnos que, veinte años después, pasase seguramente de los cuarenta.

7 FERNÁNDEZ MARTÍN. En torno a la..., p. 376.

${ }^{8}$ Según Ferreras: "El rey de Francia había enviado a Italia al duque de Enguien por general de sus armas, y había reforzado sus tropas, concurriendo a ellas voluntariamente mucha nobleza de Francia. El duque hallándose con buen exercito entró en operación y sitió a Cariñano, bloqueó a Quiers y puso en estrecho las plazas circunvecinas. Estaba en Cariñano por comandante Miguel Perea, noble y valeroso español, con presidio de españoles e italianos, que defendió aquella plaza valerosamente de los primeros ataques de los franceses, más levantándose en ella cierta emulación de los soldados sobre ser español el cabo, le fue preciso al marqués del Basto embiar a aquella plaza a Pirro Colona, cabo italiano y de gran crédito, con 600 italianos y otros tantos españoles, con que entró en Cariñano”. FERRERAS. Synopsis histórica... p.302.

${ }^{9}$ El 5 de julio de ese año Carlos V le daba dicho nombramiento, precisando que no habría de cobrar sueldo de capitán de trincheras hasta que fuese a servir dicha plaza. FERNÁNDEZ MARTÍN. En torno a la ..., p.378. 
contra los franceses. En estos años, en la región del Piamonte, es cuando lo vemos al mando de la defensa de la plaza de Carignano. Durante este tiempo debe proseguir su andadura con el ejército de Italia, pues cuando el ejército imperial, concentrado en Alemania, ante la amenaza del turco Solimán, recibe los refuerzos de las tropas de Italia, debió marchar con ellas, ya que lo vemos participar en las guerras de Alemania, y "en la jornada de Viena contra el turco" $"$.

Según Fernández Martín este mismo año de 1532 está de guarnición en la fortaleza de One ${ }^{11}$, en la costa africana. Tal vez su precipitada llegada a esta plaza tuviese lugar como consecuencia de las obras de reparos y fortificaciones que, a finales de 1531, se estaban llevando a cabo en las plazas de One, Orán, Bugía y Melilla ${ }^{12}$. A primeros de febrero del siguiente año 1533, convaleciente de una enfermedad, pasa a Málaga donde reside su mujer, permaneciendo en esta ciudad hasta el 31 de mayo, habiéndosele ordenado durante este tiempo, como a "persona que tiene experiencia de las cosas de la guerra”, que se encargase del armazón de ciertas fustas que se armaban en ese puerto dispuestas a salir contra los moros. En mayo de 1535 se le daba de baja en la capitanía de Vasco de Acuña, asistiendo en julio de ese mismo año, junto con el ingeniero Pedro Librano y el capitán de trincheras Juan Martínez ${ }^{13}$, a la toma de la Goleta ${ }^{14}$, dedicándose preferentemente a partir de entonces, y durante al menos una veintena de años, a las cosas tocantes al servicio de la armada del mar"15.

${ }^{10}$ SANDOVAL Historia de la vida..., $2^{a}$ parte, p. 362. El sitio de Viena se levantaba a mediados de septiembre de 1532.

${ }^{11}$ La plaza de One ya aparece reseñada en la carta catalana de 1375. En el Portulano de Joan Martines, de 1570, Oni aparece reseñada a la otra parte del río Muluya, tras una pequeña ensenada, frente a un islote. Dicha ensenada se corresponde con la actual "plage Madrid” de Rachgoune, en la costa argelina.

${ }^{12}$ El 6 de septiembre de 1531 se envía real cédula a los oficiales de la Casa de Contratación para que entreguen cierta cantidad de clavazón al enviado de Juan López de Recalde, proveedor de Diego de Cazalla, pagador de la armada, para los reparos y fortificaciones que han de hacerse en las ciudades de One, Orán, Bugía y Melilla. AGI. Indiferente, 1961, L.2, F.94v.

${ }^{13}$ APARICIY GARCÍA, José. Continuacón del informe sobre los adelantos de la Comisión de la Historia en el Archivo de Simancas. Segunda Parte. Trata de la Artillería e ingenieros en el siglo XVI. Madrid, Imprenta Nacional, 1849, p. 25.

${ }^{14}$ APARICI. Continuación del informe ..., P.3.

${ }^{15}$ FERNÁNDEZ MARTÍN. En torno a la..., p. 379. 


\section{Su andadura por el mar}

Siguiendo a Sandoval, vemos que en 1537 se le enviaba con cuatro navíos ${ }^{16}$ de la guarda de la costa de Andalucía a reforzar la flota de Blasco Núñez Vela, ante la amenaza de la numerosa armada que los franceses pensaban enviar a las Indias [1]. El documento que debió manejar Sandoval es la carta que el emperador envía a Blasco Núñez Vela, fechada en Monzón el 4 de septiembre en la que le comunica, entre otras consideraciones, que le envía como refuerzo la escuadra que se había aderezado para la guarda de la costa, ante el aviso que en Bretaña se estaban aderezando cinco navíos gruesos y se aparejaban otros ocho, "que son por todos trece", con la intención de embarcar tres mil hombres y dirigirse a La Habana, y de allí a Nombre de Dios y costa de Tierra Firme con el propósito de saquear sus ciudades ${ }^{17}$. En referencia a Perea le indicaba:

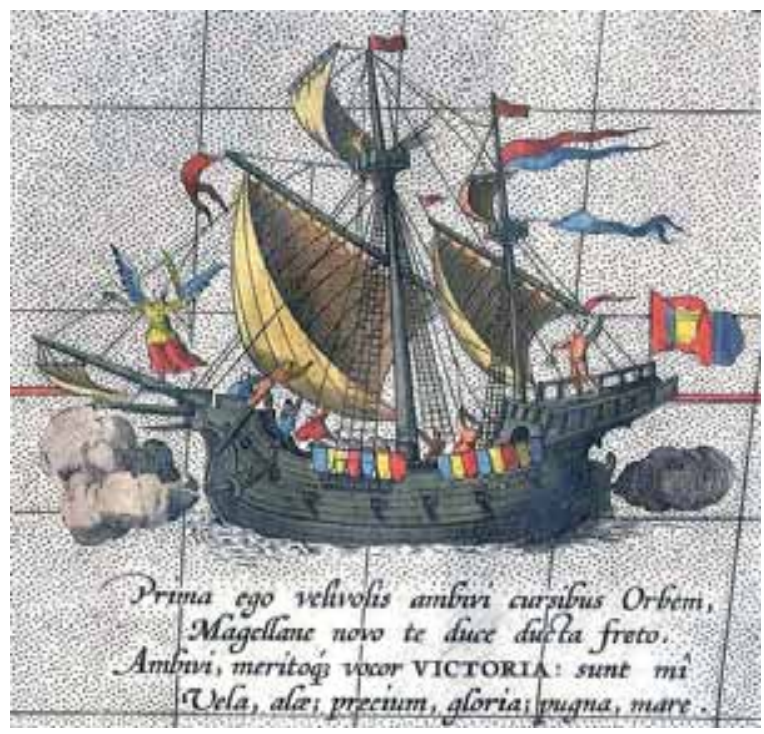

Fig. 1. Nao del siglo XVI.

\footnotetext{
${ }^{16}$ En realidad fueron tan solo dos, como veremos.

${ }^{17}$ Archivo General de Indias (AGI). Patronato, 258, N.1, G.1, R.1. La ficha del archivo aparece reseñada con fecha 9 de septiembre de 1531. Dado, en general, lo riguroso de las noticias dadas por Sandoval, hemos de señalar que en la data que aparece al final del documento tan solo aparece escrito: Monzón, 4 de septiembre, sin año, y que al principio de la carta, y con otra letra, se anota: de Monzón 4 de septiembre de 1531, por lo que nos inclinamos a pensar que la fecha correcta es la indicada por Sandoval, lo que al parecer confirman las noticias de 1536.
} 
"avemos acordado quel armada que aviamos mandado aderesçar para la guarda de la costa, se vaya luego en seguimento vuestro derechamente al Nombre de Dios, y donde quiera que os topare la persona que la llevare a cargo, que será el capitán Miguel de Perea, vos la entregue y haga lo que vos de nuestra parte le mandardes, porque dende entonces han de estar a vuestra gobernación, luego que llegaren dichas naves, las recogéis y hazed poner en orden”.

Esta escuadra que va a mandar Perea deben ser los tres navíos que en agosto de 1536 se están aprestando para engrosar "la armada de guarda de la carrera de Indias” y que, como se indica, están al mando del capitán Miguel de Perea ${ }^{18}$. El mismo día se encargaba a Miguel de Herrera, capitán general de la artillería, que armase y artillase las naos que tenían que reforzar dicha armada, y se le comunicaba el nombramiento de Perea como capitán general de dichos navíos ${ }^{19}$. En otra cedula que se enviaba a Perea se le ordenaba que preparase la salida de su escuadra, señalándole que tenía que ir con ella a las Azores $^{20}$. Días después el licenciado Suárez de Carvajal comunicaba desde Sevilla a la emperatriz que, tras haberse reunido en consulta con los pilotos y maestres ancianos para que le diesen su parecer, se habían enviado instrucciones a Miguel de Perea, “capitán de los tres navíos de Málaga”"21. Así mismo se le había nombrado capitán general de los 250 hombres que debían embarcarse $^{22}$. Durante el siguiente mes las órdenes que envía el emperador a los funcionarios de la Casa de Contratación de Sevilla y a los proveedores de la armada en Málaga, girarán en torno al aprovisionamiento de esta escuadra, y a los salarios de los maestres y gente que habrían de embarcarse, así como el que tenía que pagársele a Miguel de Perea [2].

A principios de noviembre la reina comunicaba a Miguel de Herrera y al contador Pedro del Peso, que había mandado a Miguel de Perea, "nuestro capitán de trincheras”, que fuese como capitán de los navíos que se estaban

\footnotetext{
${ }^{18}$ Valladolid 23 de agosto 1536. AGI. Indiferente 1962, L.4, F.155-156. Real cédula al licenciado Juan Suárez de Carvajal, consejero de Indias.

${ }^{19}$ Valladolid 23 de agosto de 1536. AGI. Indiferente 1962, L.4, F.161-162. La cédula del nombramiento de Perea aparece anotada a continuación. F.162r-162v.

${ }^{20}$ Valladolid 23 de agosto 1536. AGI. Indiferente 1962, L.5, F.224-225.

2130 de agosto 1536. AGI. Indiferente 1092, N. 162.

2228 de agosto 1536. AGI. Indiferente 1962, L.4, F.162v-163v.
} 
armando en el puerto de Málaga ${ }^{23}$ para acrecentar la armada que se debía hacer para la guarda de los navíos que iban y venían de las Indias, "en que se ocupará dos meses”, y por ello les mandaba que durante este tiempo en que Perea debía andar en dicha armada se le pagase "la quitación que de nos tiene en la dicha nuestra artillería por nuestro capitán de trincheras” ${ }^{24}$.

Después de casi seis meses de órdenes, preparativos, y nombramiento, al parecer esta armada de refuerzo no llegó a salir de Málaga, pues el 23 de noviembre se cursaba orden a Miguel de Perea "para que habiéndose acordado deshacer dicha armada”, la llevase a Cádiz y desembarcase toda la artillería, haciendo entrega de ella ${ }^{25}$.

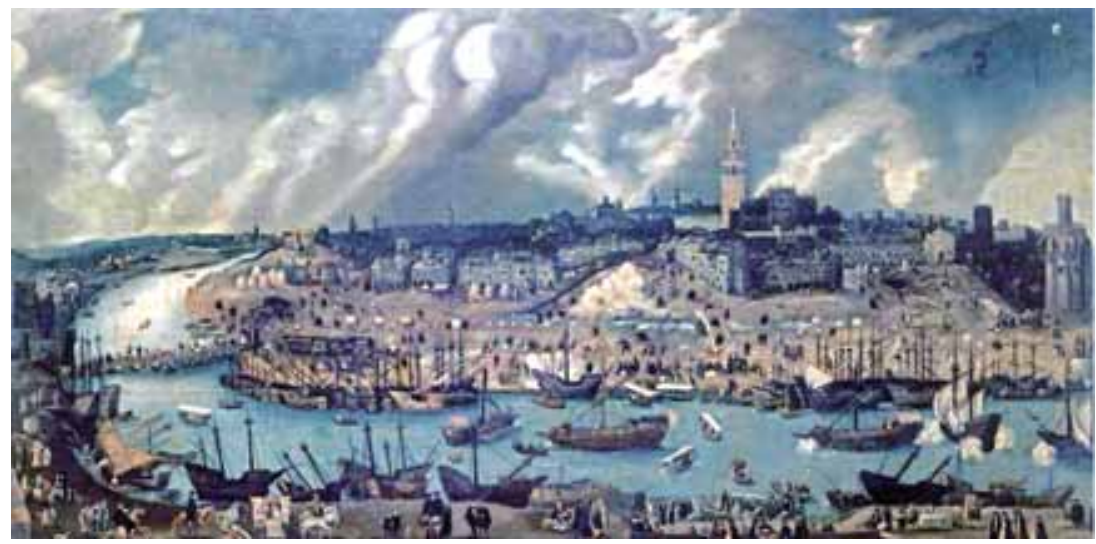

Fig. 2. Puerto de Sevilla a mitad del siglo XVI.

\section{La armada de Canarias y el apresamiento del galeón francés}

En enero de 1537 se le daba el mando de una armada compuesta por un galeón y una carabela, que debían salir en guarda de la flota de Indias, acompañándola hasta dejarla a salvo en las islas Canarias ${ }^{26}$.

\footnotetext{
${ }^{23}$ En las Atarazanas reales de Málaga estaba establecida la fundición más importante de piezas de artillería, municiones y arcabuces, con que contaba la corona en esos años. También se depositaban allí las diferentes piezas usadas que se traían, sobre todo de Alemania.

${ }^{24}$ AGI. Indiferente 1962, L.5, F.37v-38. 6 de noviembre de 1536 y AGI. Indiferente 422, L.17, F.71r-71v.

${ }^{25}$ AGI. Indiferente, 1962, L.5, F.51r,51v.

${ }^{26}$ Carta de 3 de enero 1537. AGI. Indiferente 1962, L.5, F.68r-68v.
} 
Los diputados de los mercaderes junto con el licenciado Sandoval, representante del Consejo de Indias, habían acordado que las dos naves que se habían armado y aderezado en el puerto de Málaga para que fuesen a la guarda de dicha la flota, y que la emperatriz había confiado a Perea, fuesen las siguientes: una carabela, la San Miguel, al mando de Simón Lorenzo, portugués del Algarve, natural de Tavira, que iría como almirante de la armada; y un galeón vizcaíno de la armada de guarda, el San Nicolás, al mando de Nicolás de Lezo, que llevará por piloto a Juan Trabuco. Perea, provisto de su instrucción ${ }^{27}$ salió de Málaga para reunirse con la flota de Indias, que iba al mando de Blasco Núñez Vela, zarpando todos juntos del puerto de Cádiz el 6 de enero de ese año 1537 rumbo a la Gomera, a la que llegaron tras nueve días y medio de navegación.

La flota se detuvo cuatro días en el puerto de la Gomera repostando agua y leña, al cabo de los cuales zarpó rumbo a las Indias. Perea aún se detuvo otros tres días más en la isla, dirigiéndose luego a la Palma en busca de dinero para repostar vino, agua, pan, leña y otras cosas que necesitaban, consiguiendo del gobernador que le enviase cien fanegas de trigo, y la promesa de darle todo cuanto necesitase. Proveyéndose de todo ello y confeccionando bizcocho pasaron en la isla casi un mes, hasta que el miércoles 7 de abril 28 “ocho días antes de carnestolendas", pasadas dos horas del mediodía, "a la hora de vísperas", estando embarcando el bizcocho y otras avituallas que habían comprado, vieron llegar al puerto de Santa Cruz tres naves dando caza a una carabela del Algarve, la Galgaves, del maestre Pedro Lorenzo, que venía de pesquería y trataba de refugiarse en el puerto, y dieron por supuesto serían las naos francesas que se encontraban en Lanzarote, de las cuales le habían llegado noticias desde Gran Canaria el día anterior.

\footnotetext{
${ }^{27}$ Según relataba Perea, una de las instrucciones, en la que se recogían los capítulos y condiciones por los que habría de regirse durante el tiempo de su mando, le había sido enviada a Málaga por los diputados de la armada de las averías. Estos serían los que le pagarían su sueldo y correrían con todos los gastos que generase la armada, y recibirían a cambio, a más del impuesto que ya cobraban, el $50 \%$ de toda posible presa. El Consejo le había enviado a Perea una cédula en la que se le ordenaba que diese de comer a los maestres de las naos que llevaba, y a la gente de guerra, que luego se le pagaría a razón de 19 maravedís al día por cada marinero, medio real por cada soldado, y 25 maravedís por cada artillero. AGI. Justicia, 1172,N.2,R.4.

${ }^{28}$ Archivo General de Simancas (AGS). Cámara de Castilla (CCA), Diversos (DIV), 13,53.
} 
$\mathrm{Al}$ entrar en puerto, las naves francesas pusieron sus velas mayores y trinquetes de gavias, "a manera de guerra”, izaron las banderas y estandartes e hicieron sonar las trompetas y atabales, con la intención de espantar y hacer salir del puerto a las naves que se encontraban surtas en el mismo, pensando que serían todas ellas de mercancías ${ }^{29}$. Comenzaron a disparar su artillería gruesa al pueblo, desde donde le respondieron con algún tiro de la pieza que el Cabildo había hecho montar "a la costa de la mar de dicho puerto".

El almirante Simón Lorenzo, que nada más divisar las naves a lo lejos había hecho embarcar rápidamente a su gente, soltó el batel, cortó amarras, y levando anclas salió a por ellas, adelantándose al galeón de Perea “y el piloto mayor de la capitana le dio aviso que el capitán general mandaba que no fuese por delante de ellos" a lo que éste replicó que no quería que lo cogiesen con el ancla echada, y prosiguió su acción. Puso la carabela a barlovento de las naos francesas, en posición ventajosa, y contestó con su culebrina al disparo que le habían hecho con una lombarda desde una de las naves francesas, las cuales, viendo que había en el puerto naves de armada, volvieron la espalda y salieron huyendo. Pero la carabela de Lorenzo, "más rápidas que ellas, las alcanzó y les tiró hasta dieciséis tiros de artillería”, estando peleando ella sola con las tres naos francesas todo aquel día hasta la caída del sol, en que se les unió el galeón de Nicolás de Lezo, donde iba embarcado el general.

Al tiempo que salía la carabela de Lorenzo, la capitana permanecía en el puerto embarcando bastimentos y a su gente, que se encontraban en tierra, tras lo cual, ya anocheciendo, salió también en persecución de las naves francesas, "hacia el Sudoeste, abajo de la isla del Hierro", a las que alcanzó, como vimos, “cuando ya se quería poner el sol”. Aún hizo algunos disparos a la nao capitana francesa, sin acertarla, y como sobrevino la noche, aguardaron a la llegada del día, dejando de disparar “a la ora de las ave María”. A la mañana siguiente, amaneciendo, vieron que dos de las naves francesas, aprovechando la oscuridad de la noche, habían desaparecido, quedando tan solo la capitana de ellas, que con todas las velas desplegadas iba huyendo, y fueron tras ellos, siendo la carabela la primera en alcanzarlos, porque al galeón se le había

\footnotetext{
${ }^{29}$ AGS .CCA.,DIV, 13,1.
} 
desmochado la vela del trinquete de avante. "Y comenzaron a jugar la artillería”, tirándoles también con los arcabuces y diversas "alcancías” ${ }^{30}$ que les arrojaron, matando a más de veinte de ellos y dejando malherido en una pierna y quemado en la cara a su capitán ${ }^{31}$.Y estando en esto, llegó Miguel de Perea con su galeón, que habían podido reparar, y abordó a la nao por la banda de babor, mientras la carabela lo hacía por la de estribor, y saltando la gente a la nao francesa, la rindieron. Sacaron de ella todo lo que llevaba de valor, y metieron gente para gobernarla, uniéndola a las dos que llevaba de armada.

Veamos cómo habían llegado a Canarias las naves francesas que se enfrentaron a las dos de la armada de guarda ${ }^{32}$. En los primeros días de enero de 1537, al tiempo que salía de Cádiz la escuadra de Perea, partían del puerto de "Habranueva, junto al río de Ruan"33 una nao nueva, "de primer viaje" que pertenecía al rey de Francia, recién equipada y bien armada para el corso $^{34}$, al mando de un pariente de dicho rey llamado "monsior Francisco Mayhet"... "señor de Bonabo", con la intención "de hacer la guerra contra la gente del Emperador,” y un galeón pequeño al mando del capitán Roberto Bri, que había salido "del puerto de Breste en la costa de Bretaña” y se les

${ }^{30}$ Vasijas de barro rellenas de pólvora y trozos de hierro colado, que se arrojaban a manera de bombas de mano.

${ }^{31}$ Bonabo fallecía en la Palma poco tiempo después. El 7 de septiembre se le preguntaba a Perea sobre los gastos que se habían hecho en el entierro del capitán del galeón francés. AGI. Indiferente, 1962, L.5, F237-239.

${ }^{32}$ Sobre este hecho, además del extenso capítulo que escribió Antonio Rumeu, existen numerosos autores que lo citan, aunque alguno de ellos con ligeros errores que van pasando de unos a otros, llegando a convertir a las dos naves francesas a las que se enfrenta Pera, en doce e incluso en ochenta. RUMEU DE ARMAS, Antonio. Piraterías y ataques navales contra las islas Canarias. CSIC. Instituto Jerónimo Zurita, Tomo I, 1947; TOUS MELIA, Juan. El cañón Escorpión. De la Torre de Londres al Castillo de Santa Catalina en la isla de La Palma. San Cristóbal de la Laguna 2007, p.61; CASTILLO, Pedro Agustín, SANTIAGO, Miguel. Descripción histórica y geográfica de las Islas Canarias. Las Palmas 1965, p.864; CASTILLO MATHIEU, Nicolás del. La llave de la Indias. Ediciones ElTiempo, Bogotá, 1981, p.41; LUCENA SALMORA, Manuel. Piratas, bucaneros, filibusteros y corsarios en América:perros, mendigos y otros malditos del mar. Grijalbo 1994, pp.57, 313; FERNÁNDEZ DURO, Cesáreo. Armada Española, Tomo I, Madrid 1895, p. 207.

${ }^{33}$ Le Havre, a la entrada del río de Rouen.

${ }^{34}$ Estaba armada con 10 piezas gruesas de hierro "que llaman pasavolantes"; media culebrina de bronce "que tira hierro colado", "que tiene flores de lis"; 14 versos de hierro; 5 o 6 arcabuces; algunas ballestas; y cantidad de munición de echar fuego a mano o "botafuegos". 
había unido para salir en armada rumbo a las islas Canarias con el propósito de capturar alguna da las naves que hacían la ruta de las Indias ${ }^{35}$.

Camino de Canarias, a unas 60 leguas del cabo de San Vicente,"a la parte de las Indias” una noche, el galeón pequeño capturó la nao del maestre Juan Gallego, que iba cargada con más de 80 cajas de ricas ropas, fardos de lienzos, paños, y casi medio centenar de esclavos, que llevaban a las Indias. Había salido con la flota que partió de Sanlúcar de Barrameda el 14 de enero al mando del capitán Peran Arias ${ }^{36}$, pero a esa altura de la navegación les cogió un fuerte temporal que dispersó las naves. Y ese día capturaron también las naos de Nicolao de Nápoles y de Mateo de Vides, tomando todo lo de valor que llevaban, "que cada una estaría cerca de los 25.000 ducados". Durante el combate la nao de Gallego resultó dañada, de manera que empezó a entrarle agua y tuvieron que pasar a ella gente de ambos navíos con el fin de achicarla, consiguiendo con gran trabajo llevarla a Lanzarote con la intención de repararla. Al entrar a puerto, que fue el 25 de enero, encontraron fondeada parte de las naves de dicha flota de Indias las cuales, al verlos llegar, se dispersaron, huyendo cada una por donde pudo, logrando no obstante capturar a una de ellas, la Marieta, nao del maestre portugués Diego Martín. Como la nao de Gallego se hundía, pasaron a ella y sacaron toda la mercancía de valor y la repartieron entre ambos navíos, metiendo en la nao de Bonabo más de la mitad de las cajas. Y después, sacando de ella todo lo que se pudo la arrimaron a la costa, dejando dentro todas las pipas de vino que llevaba, así como harina y otras cosas, todo lo cual se lo dieron a los dos maestres capturados, diciéndoles que se repartiesen lo que quedaba "para que se remediasen”, dejándoles también 30 de los esclavos. Luego las naves francesas salieron hacia el puerto de la Palma con el fin de aprovisionarse de agua, de la que iban faltos y necesitaban para poder "volverse a Francia a llevar la presa" con la intención "que devuelta

${ }^{35}$ Según declaración de ciertos mercaderes que habían apresado en la nave de Juan Gallego, unos decían que los marineros franceses hablaban sobre la salida de nueve navíos de armada del puerto de "Abranueva", otros declaraban que les habían oído hablar que andaban en esas aguas cuarenta naos, de siete en siete (AGS. CCA, DIV, 13,1), aunque según declaraban posteriormente estos franceses, ya prisioneros, salieron tan solo estas dos naves que especificamos (AGI. Justicia, 1159, N.9).

${ }^{36}$ AGI. Indiferente 1092, N.204. 
habrían de volver al paraje donde vienen las naos del Perú y Nueva España, y no se les había de escapar ninguna" 37 , y estando navegando hacia la Palma fue cuando se encontraron con las naves de Miguel de Perea [3].

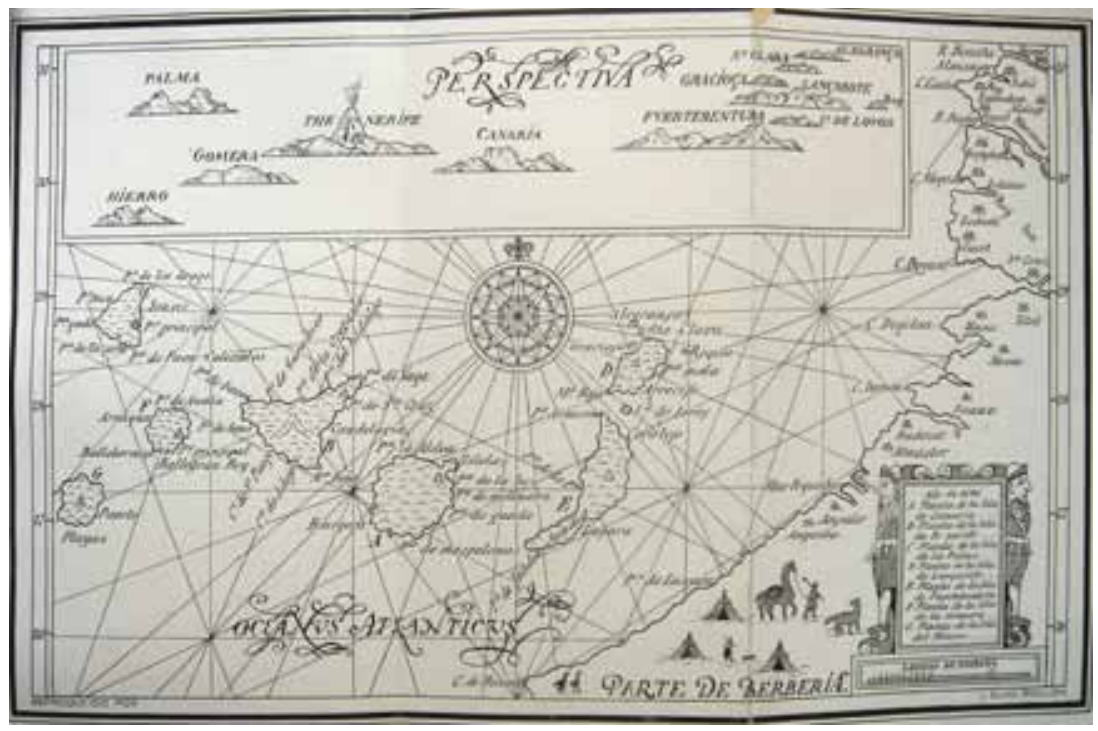

Fig. 3. Islas Canarias y costa de Berbería 1686.

Después de tomada la nao francesa, la escuadra de Perea se mantuvo navegando por esas aguas cerca de un mes en busca de franceses, regresando al puerto de la Palma el 3 de marzo, habiendo sufrido muchos días de mal tiempo y fuertes vendavales, que les dañaron las amarras y les hizo perder alguna de las anclas, de manera que fue necesario permanecer en la isla más de dos meses recogiendo víveres, limpiando las naos, y reparando las velas y aparejos, que habían resultado dañados a causa de dichos temporales y de los combates que habían sostenido. Durante el tiempo que permanecieron en la Palma, fueron a Tenerife con el propósito de enrolar gente para reforzar las tripulaciones y soldados, y poder navegar por las islas de Canaria, Lanzarote y las Azores en busca de franceses. Durante los siete u ocho días que estuvieron en Tenerife, Perea fue agasajado por la gente principal de la isla, que organizaron en su honor juegos de cañas y toros, además de llevarlo a cazar

${ }^{37}$ AGS. CCA. DIV. 13,1. 
por la isla. De allí pasaron a la isla de Canaria donde, juntamente con algunos de sus soldados de confianza, fueron igualmente festejados, jugando nuevamente a cañas y corriendo algunos toros. Durante todo el tiempo que permanecieron en las islas Perea, como a quien correspondía por su estamento, estuvo haciendo regalos a todas las personas que se le acercaban y le halagaban, "y como sabían que daba mucho, venían muchas personas a verlo y a hablar con él, y a todos les daba de las dichas joyas, y así mismo a frailes y abades les dio para ornamentos de iglesias muchas sedas de colores."

Estando en la Palma, recibieron aviso del conde de la Gomera de que en el puerto de la Gomera había dos naos y una carabela francesas, y salieron en su busca pero cuando llegaron a la isla, las naves ya se habían marchado, así que regresaron a Palma, donde debido al mal tiempo que les hizo y a estar terminando de cargar provisiones, estuvieron casi dos semanas, "y cada día toreaban y jugaban cañas y corrían la sortija” al cabo de las cuales salieron hacia "la isla de la Madera", con el fin de recoger el oro y la plata, que habían traído los maestres Pedro Marques y Juan Bautista, y llevarlo a España.

A finales de marzo los oficiales de la Casa de Contratación escribían a su majestad comunicándole que la flota había partido hacia las Indias el 6 de enero, y que los dos navíos que el capitán Miguel de Perea llevó con ella, habían sido proveídos para dos meses, y que había pasado ya medio mes del plazo previsto y no se sabía nada de ellos, aunque les habían informado que había llegado con la flota a las Canarias, haciendo la travesía en pocos días. La preocupación por su tardanza, decían que era debido a que ya hacía muchos días que esperaban en Sanlúcar más de 20 navíos dispuestos para partir a la Indias, y era preciso despacharlos ${ }^{38}$.

Según se quejaba el diputado de los mercaderes de la armada, que eran los que habían pagado a Perea los pertrechos, sueldos y todo lo demás necesario para sus dos naves, a costa "de las averías que cogían y pactaban los puertos" ${ }^{39}$, éste no les había dado cuenta ni razón de las cuantiosas mercan-

\footnotetext{
${ }^{38}$ Carta de 23 de marzo 1537. AGI. Indiferente, 1092, N.204.

${ }^{39}$ La avería, o derecho de avería, era un impuesto ad valorem sobre el comercio colonial de los siglos XVI y XVII. Se imponía sobre los mercaderes o las mercancías, incluyendo así mismo los pasajeros que pasaban a Indias.
} 
cías y otros bienes que había apresado, que según ellos valdrían más de 30.000 ducados, junto con veinticinco o treinta franceses ${ }^{40}$, que había enviado en una carabela, que entró en Puerto Real. Solicitaban que se le pidiesen cuentas y que redactase un inventario de todo lo apresado ${ }^{41}$.

Mientras tanto los diputados seguía requiriendo ante los oficiales de la Casa de Contratación que se tomasen cuantas a Miguel Pera y a sus soldados de lo que tomaron en el galeón francés que habían apresado. Los oficiales escribían al rey comunicándole que no habían hecho nada al respecto para no impedir ni estorbar los preparativos de la armada. Le advertían también que le llegarían quejas de Perea y algunos de sus soldados, porque todavía no se les había pagado, como ya se había hecho con todos los demás. Decían que ellos no habían pagado a aquellos soldados de los que tenían información que habían robado y saqueado del galeón francés más cantidad de ropa de la que les pudiese corresponder en función de su sueldo, y de la parte de la presa que les era lícito tomar. Le enviaban los testimonios que se habían recogido sobre la negativa de Perea a entregarles una esclava que había cogido y se había llevado a su casa, indicando que era una de las que el galeón francés había tomado de la nao de las Indias, y que por tanto debería ser devuelta a su dueño ${ }^{42}$.

Insistían los diputados ante su majestad solicitándole que se nombrase a una persona para que tomase cuenta de lo recaudado por el impuesto de la avería, y lo gastado en la armada, y decían que las cuentas estaban bastante claras a excepción de la que se tenía con Miguel de Perea por su viaje a Canarias, cuyas deudas no las registraban hasta tanto no se les indicase cómo habían de proceder con ellas. Según tenían noticias, había cogido prendas por valor de más de doce o quince mil ducados, y la mayor parte de ellas eran de mercancías que pertenecían a gente de Sevilla, que la nao francesa había to-

${ }^{40}$ En septiembre de 1537 los diputados decían que tenían presos 48 franceses que había traído Miguel de Perea, y que los estaban manteniendo mientras discutían el precio (1.500 ducados) de su rescate. AGI. Indiferente 1092, N.237 y N.241. En la Palma había dejado otros 20 de los cuales, al parecer, había negociado directamente el rescate de al menos de dos o tres de ellos, "gentilhombres de Francia que son hombres de renta”, entre los que se encontraban el alférez de Bonabo y un tal Bern.

${ }^{41}$ Carta de 2 de abril 1537. AGI. Indiferente 1092, N206.

${ }^{42}$ Carta de 9 de mayo 1537. AGI. Indiferente, 1092, N.225. 
mado de dos naves que salieron de esta ciudad hacia las Indias. Como hasta ese día Perea seguía sin haberles dado cuenta de todo ello, suplicaban que se le mandase les diese cuenta y razón de todo aquello que había cogido del galeón francés que había apresado ${ }^{43}$.

El 10 de julio todavía no se tenían en Sevilla noticias directas de Perea, pero había llegado desde Madeira una carabela portuguesa cuyos tripulantes dijeron que lo habían visto en aquella isla, junto con sus tres navíos, y que allí recogió todo el oro y plata que había traído el maestre Pedro Marques, y también lo que había dejado el maestre Juan Bautista, y que todos juntos habían salido hacia España, pero habiendo navegado unas treinta leguas, las naves de Perea, que no andaban tanto como su carabela, se habían quedado atrás. Le indicaban a Tello que ellos pensaban que entre hoy o mañana, estaría al llegar a Sanlúcar o a Cádiz ${ }^{44}$. No sería hasta el martes 24 de julio, víspera de Santiago, el día en que Perea entraba con sus navíos en la bahía de Cádiz, lo cual comunicaba por carta al tesorero Tello, junto con las noticias que ya sabía éste sobre el oro que había recogido en Madeira ${ }^{45}$.

En otra carta enviada a su majestad por el tesorero Tello, el contador Diego de Zárate y el factor Diego Caballero, en la que le daban noticias referentes a diversos asuntos propios de la Casa de la Contratación, le comunicaban también otras sobre Perea ${ }^{46}$. Decían que les había llegado de Cádiz la relación e inventario de todo lo que había tomado en la nao francesa y la información que sobre ello se hizo, y que todo ello se lo enviaban para que mandase lo que fuere servido, no obstante ellos pensaban que dichas cuentas necesitaban cierto tiempo para ser aclaradas, y que trabajarían sobre ello para averiguar todo lo que habían recibido de gracia en las islas Canarias durante el tiempo que estuvieron allí. Referente a lo que se les mandaba de proveer gente, y si fuese necesario les adelantasen dinero, para la nueva salida que debía hacer el capitán con los tres navíos que trajo, y los otros tres que se tenían que armar, le comunicaban que la gente estaba empeñada en que se les

\footnotetext{
${ }^{43}$ Carta de 28 junio 1537. AGI. Indiferente, 1092, N.214.

${ }^{44}$ Carta de 10 julio 1537. AGI. Indiferente, 1092, N.125.

${ }^{45}$ AGI. Indiferente, 1092, N.228.

${ }^{46}$ AGI. Indiferente, 1092, N.218.
} 
pagase todo el tiempo que habían servido y estado en las islas Canarias, y que habían advertido que una vez cobrasen "por ninguna cosa se irán a servir en la armada", y por todo esto, y por no tener que mantenerlos durante el tiempo que se aderezaba la armada, habían dispuestos que se les despidiese porque, teniendo dinero para ello, enseguida se encontraría toda la gente que fuese menester para dicha armada. Le comunicaban también los problemas que tenían para conseguir que los diputados de la armada adelantasen dinero con la garantía de las averías ${ }^{47}$.

A los cuatro días de haber arribado Perea al puerto de Cádiz, Alonso Núñez, diputado "de la avería del uno por ciento para la armada”48, estando en la nao francesa que había apresado Perea, que se encontraba surta en dicho puerto, en presencia del escribano Alonso de Medina y de algunos testigos, le entregaba un requerimiento, que fue leído en su presencia. El diputado decía que el capitán, con la armada a su mando, había apresado una nao francesa de la que era capitán mosior de Bonabo, con muchas ropas, mercaderías, artillería, municiones, y oro y plata, y que todo ello era considerado como botín de su majestad, por lo que se le pedía diese cuenta de todo lo que se había tomado de dicha nao ${ }^{49}$.

El requerimiento real dirigido a Perea decía que, por parte de los diputados de la armada de guarda de las costas de Andalucía, se le había hecho relación de su salida del puerto de Sanlúcar de Barrameda con una armada, compuesta por un galeón y una carabela, en guarda y conserva de una flota de naos que iba a las Indias, para llevarla hasta las islas Canarias, las cuales habían sido proveídas y aparejadas a costa de las averías que se recaudaban para los gastos de la armada, y que estando allí recorriendo las islas en busca de corsarios franceses, se enfrentó a una nao francesa, de la que era capitán

\footnotetext{
${ }^{47}$ En carta del 28 de julio los oficiales de la casa de Contratación se lamentaban de lo poco que se recaudaba con el impuesto de averías porque había cesado el trato con las Indias, y por temor a los franceses no iban ni venían las naos de Flandes y Levante o de otras partes, como solían. AGI. Indiferente, 1092, N.217.

${ }^{48}$ Aunque se comenzó cobrando este $1 \%$ pronto subió al 2,5\%, porcentaje que no dejaría de crecer desde 1587 con el aumento de la amenaza de los piratas franceses e ingleses, llegándose en ocasiones al 30\%.

${ }^{49}$ Cartas de 28 julio 1537- 1 septiembre 1537. AGI. Justicia, 1159, N.9.
} 
Francisco Mayhet, señor de Bon Bost ${ }^{50}$ tomándole la artillería, munición y ciertas mercaderías y otras cosas que en ella había, y que según la instrucción que se le había dado en 20 de abril de ese año 1537, la mitad de todas las presas que hiciese en dicho viaje sería para él y su gente, y la otra mitad para los gastos de dicha armada, y que por tanto, dichos diputados, le suplicaban que le mandase dar cuenta y razón de todo lo apresado, y que les entregase la mitad de todo ello, lo que le ordenaba al efecto.

El diputado Alonso Núñez, requirió también a Juan de Borgoña, pues tenía noticias que había regresado como maestre de la nao apresada y que había recibido todo lo capturado al francés, y que así mismo los demás habían dado cuenta y razón de todo ello, y como conveniente al servicio de su majestad, debía darle también dicho Borgoña cuenta de ello, so pena de embargarle de sus bienes 20.000 ducados, que era lo que podía valer la presa que se tomó de la nao, advirtiéndole que no se la pagaría a él ni a su gente lo que le correspondía por el viaje. Borgoña replicaba, que en efecto, estando él desembarcado en el puerto de la Palma cuando llegó el capitán Perea con la nao francesa, éste le había nombrado maestre de la misma, y había embarcado un capitán con su gente, y que él tan solo se encargó de ser el maestre, y que además cuando él llegó ya estaba sacado todo de dicha nao, y por lo tanto no estaba obligado a dar ninguna cuenta ${ }^{51}$.

Las reclamaciones contra Perea se sucedieron a los largo de los años, sin que al parecer la corona interviniese de una manera efectiva para hacer que Perea entregase, según lo capitulado, la mitad de lo que realmente había apresado. Por lo visto andaba más interesada en los buenos servicios que le prestaba el capitán que en intervenir en reclamaciones económicas, como esperaba el propio Perea el cual, estando a punto de partir hacia Tierra Firme, escribía al rey diciéndole que "iba muy contento de ello, y lo fuera mucho más si no me pusiesen pleito a una miseria que ganamos con

\footnotetext{
${ }^{50}$ No hemos podido aclarar cual era el verdadero nombre de este personaje, que como veremos era pariente del propio rey de Francia. En la documentación aparece como Francisco Mayhet, señor de Bon Bost; monsior de Bayan; monsior de Bonbo; Bonabot; y como monsior de Bonabo que es la grafía que más se repite.

${ }^{51}$ AGI. Justicia, 1159, N.9.
} 
tanto trabajo... yo espero en Dios que Vuestra Majestad lo mandará remediar ${ }^{52}$ ". El apresamiento de uno de los galeones del rey de Francia había llenado de satisfacción al emperador, que incluso había recompensado espléndidamente a Juan Antón, soldado de confianza de Perea, que con un despacho de éste se había adelantado desde la Palma para traerle la buena nueva de la captura ${ }^{53}$.

Habiendo llegado noticias a primeros de septiembre desde Lisboa, que a las islas de las Azores había arribado una nao procedente del puerto de Nombre de Dios, la cual, según decían, traía para el monarca más de 200.000 pesos de oro, y otros 400.000 entre mercadería y lo que traían los pasajeros, se dieron ordenes para que el capitán "Mendrichaga”, uno de los que servía en la flota de guarda, no saliese con su galeón, hasta que se le ordenase otra $\operatorname{cosa}^{54}$ y así mismo para que se aprestasen los tres navíos del capitán Miguel de Perea, y se embargase y aderezase otra nao, de las mejores que pudiesen encontrar en la bahía de Cádiz. Respecto a Perea, los oficiales de Sevilla, decían que se les indicase cómo tenían que proceder en cuanto al pago de la gente que había ido con él, y advertían que si se le tenía que tomar cuentas, como insistían los diputados de las averías, no lo podrían hacer porque Perea, si salía con la nueva armada, no estaría presente, y ya hacía mucho tiempo que los soldados molestaban a los diputados y a ellos mismos para que se les pagase todo lo que se les debía. Advertían que para pagarles y aderezar la armada eran necesarios al menos diez o doce mil ducados, y por mucha prisa

${ }^{52}$ AGI. Indiferente, 1092, N.231.

${ }^{53}$ En 18 de abril de 1537 el emperador libraba una cédula para que se le pagasen 30 ducados, "que montan 11.250 maravedís", los cuales le había hecho merced por la noticia que le había traído. AGI. Indiferente, 422, L.17, F.124v. En 7 de septiembre en una cédula real enviada a Perea se le consultaba sobre la merced que podría hacerse a Juan Antón por sus servicios en la armada. AGI, Indiferente, 1962, L.5, F.237-239. Juan de Antón fue uno de los soldados que se apropió de más botín. Se le acusaba de haber tomado todo lo que se encontró en la cámara de Bonabo, donde además de ricas ropas había cantidad de dinero y joyas, botín que creemos había tomado para su general. Decían que cuando salió de Palma, llevaba cosidos en un jubón más de 900 ducados, de los dineros que había cogido en la nao francesa. AGI. Justicia, 1159, N.9.

${ }^{54}$ Juan de Mendiarechaga, marino vizcaíno, al que la emperatriz le mandaba que se pusiese a la órdenes del capitán Miguel de Perea, e hiciese todo lo que éste le mandase "como general de la armada que va a las islas Azores”, nombrándole veedor general de dicha armada. Una semblanza de este capitán en MUGARTEGUI (1927). 
que se diesen en todo ello, la armada de Perea no estaría preparada antes de mediado o finales de septiembre ${ }^{55}$.

\section{La armada a Tierra Firme}

Estando todavía Perea en las islas Canarias, a mediados de abril de 1537, y ante la noticia de la existencia de corsarios franceses que estaban al acecho en espera del oro que venía del Perú, el Consejo de Indias había enviado a su encuentro a la armada de Perea, que sabía se encontraba en aquellas aguas, y escribía a Sevilla indicando lo conveniente que sería que dicho capitán recorriese los cabos y las islas de Canarias y Azores en su busca. Les daba también instrucciones sobre la provisión de bastimentos para la nueva armada de seis naos que pensaban aprestar, las tres que ya llevaba Perea y otras tres que deberían embargarse, indicándoles que la artillería habría de traerse de Málaga ${ }^{56}$. A pesar de las noticias en su contra que daban los mercaderes de las averías, y su insistencia en que "no se le debe confiar otra cosa más importante" 57 , al menos hasta que hubiese aclarado las cuentas pendientes con ellos, o hubiese depositado la fianza correspondiente, el 18 de abril se nombraba a Miguel de Perea capitán general de las seis naos que habrían de salir en busca de $\operatorname{corsarios}^{58}$. Ese mismo día se enviaba una cédula a los diputados de la armada de guarda para que le aumentasen el salario, de 400 que cobraba, a 600 maravedís diarios, junto con otra carta en la que se les mandaba que se le pagase a dicho Perea, y a la gente de mar que le acompañaba, lo que se les debiese de sus sueldos ${ }^{59}$. Los oficiales de la casa de Contratación habían socorrido a los soldados que fueron desde Málaga con tres pagas, y a los que habían embarcado en el enganche que se hizo en las Canarias, con dos, prometiendo a los que de ellos quisiesen ir en la nueva armada, darles tres pagas en Sanlúcar; una a cuenta de lo servido, y otras dos a cuenta de lo que habrían de servir ${ }^{60}$.

${ }^{55}$ AGI. Indiferente, 1092, N.218.

${ }^{56}$ AGI. Indiferente, 1962, L.5, F.129v-131.

5727 agosto 1537. AGI. Justicia, 1159, N.9.

${ }^{58}$ AGI. Indiferente, 1962, L.5, F.136-137v.

${ }^{59}$ Valladolid 18 de abril 1537. AGI. Indiferente, 1962, L.5, F.129v-131; F.131-132v; F.133v134v; F.136-137v; F. 138v-139; F. 139r-139v.

${ }^{60}$ Carta de 31 de agosto de 1537. AGI. Indiferente, 1092, N.223. 
El tesorero de la Casa de Contratación, Francisco Tello, comunicaba al monarca que de las tres naves que se le había ordenado que embargase para completar dicha armada, todavía no lo había hecho con ninguna pues no se le había indicado cual era el porte que debían tener, y añadía en su escrito que en ese río y en Sanlúcar no había ninguna nave, y que ya había mandado averiguar las que pudiera haber en la bahía de Cádiz [4]. Le decía que además, antes de embargarlas y que estuviesen paradas en el puerto "ganando sueldo sin servir", esperaba la llegada de las tres naves que traía Perea, y mientras se aderezaban y ponían en orden, se cogerían y aderezarían las otras tres. Le consultaba también qué era lo que tenía que hacer con dos de los presos franceses que había enviado Perea desde Canarias, pues eran unos muchachos y no sabía si querría soltarlos ${ }^{61}$. El 10 de septiembre, las tres naos de Perea ya se encontraban en Sanlúcar de Barrameda, junto con el galeón de Juan de Evora, a la espera de otro galeón que se había embargado a Martín de Aquache, y que ya aprestado, se dirigía hacia ese puerto.

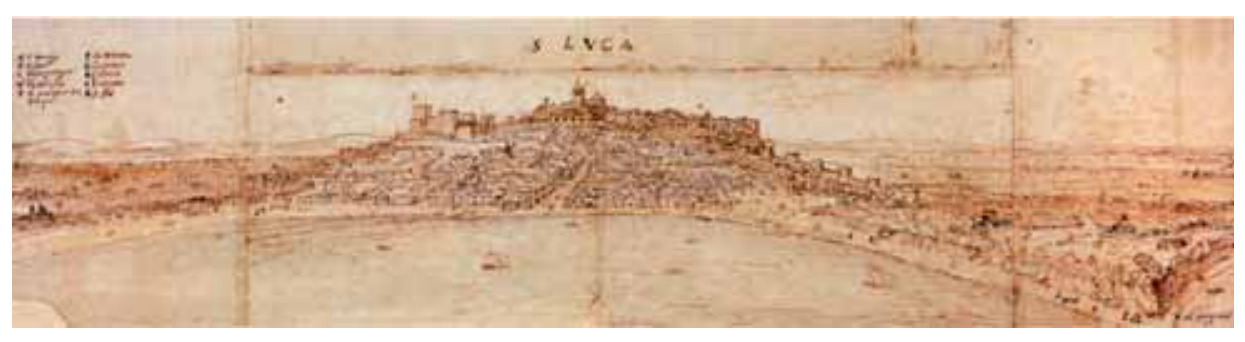

Fig. 4.Vista de Sanlúcar en 1567, por Anton Van den Wyngaerde.

Cuando ya estaba todo preparado para la salida de la escuadra de Perea hacia las Azores, se recibían noticias confidenciales de que en "Diepa, que es en Bretaña en el reino de Francia"62 estaban aprestando cinco navíos gruesos y se aparejaban otros ocho, en los que pensaban embarcar 3.000 hombres con la intención de dirigirse a la Habana, y desde allí a Nombre de Dios y Tierra Firme, con la intención de saquearlos, y aguardar en aquellas aguas la salida de las naos cargadas con el oro y la plata. El monarca el 4 de septiem-

${ }^{61}$ Carta de 2 de mayo 1537. AGI. Indiferente, 1092, N.210.

${ }^{62}$ Dieppe, puerto del que salió Jean Fleury- Juan Florín- al mando de nueve navíos, que en 1522 capturaba en Canarias la nao que traía el tesoro de Mexico. 
bre escribía a Blasco Núñez Vela, comunicándole, que después de haber hecho su salida con la flota hacia las Indias, el 6 de enero como vimos, le habían llegado dichas noticias, y que aunque él pensaba que la armada que llevaba estaba bien prevista y "era bastante para resistir y ofender a los dichos corsarios" para mayor seguridad, había acordado que la armada que se había aderezado para la guarda de la costa, fuese directamente a Nombre de Dios en su seguimiento, y la persona que la llevase a su cargo, “que será el capitán Miguel de Perea”, se la entregase y la pusiese bajo su mando ${ }^{63}$.

Aunque el monarca ya había decidido que la armada de Perea habría de cambiar su destino y en vez de ir a las Azores, saldría hacia las Indias, en las notificaciones que se suceden en estos días aún se nombran ambos destinos. El 7 de septiembre de 1537 se daba una cedula al capitán Miguel de Perea, “capitán general de las cinco naos de armada que han de ir a las Azores" para que recibiese y guardase las instrucciones que para dicho viaje habían de darle los diputados de la armada y los oficiales de la Casa de la Contratación ${ }^{64}$, y así mismo se enviaba otra cédula a dichos oficiales sobre la pretensión del capitán de que "antes de salir nuevamente a las Azores con la armada”, se saldasen sus cuentas y las de la gente que había ido con él, dándoles también instrucciones en la misma cédula sobre el aderezo "del galeón que había de ir con los otros cuatro que van a las Azores"65. Y aún se le mandaba a Miguel de Perea otra cédula en la que se le indicaba la conveniencia de diferir las cuentas que había de dar de lo tomado al galeón francés, "hasta la vuelta del viaje a las Azores" ${ }^{\text {66 }}$. Ese mismo día se nombraba al capitán Juan López de Archuleta como almirante de la armada que tenía que ir a las Azores.

Igualmente se enviaba una cédula a los oficiales de la Casa de Contratación para que aprestasen con toda diligencia las naos de armada que había de

${ }^{63}$ Esta cédula, que esta datada en Monzón a 4 de septiembre, sin especificar el año, tiene sobrescrito en su encabezamiento, con letra posterior, la fecha 4 septiembre 1531, y con ella figura en el fichero del Archivo, lo cual, al no tenerla en cuenta, nos tuvo confundido respecto al destino de la armada de Perea, sin entender cómo, con la misma fecha, se hablaba de dos destinos diferentes para la misma armada. Ver nota 14.

\footnotetext{
${ }^{64}$ AGI. Indiferente, 1962, L.5, F234v-235.

${ }^{65}$ AGI. Indiferente, 1962, L.5, F231v-234.

${ }^{66}$ AGI. Indiferente, 1962, L.5, F237-239.
} 
llevar el capitán Perea, esta vez ya se indica "hasta Tierra Firme", y saliesen enseguida a encontrarse con la armada de Núñez Vela, dando instrucciones sobre la conveniencia que la gente que tenía que ir en dichas naos "no sepan que van a Tierra Firme, sino a las Azores"67.

Dos meses más tarde, el siete de diciembre, el emperador enviaba una cédula a don Miguel de Herrera, capitán general de la artillería, ordenándole, que en vista de otra anterior dada por la emperatriz en noviembre del pasado año 1536 sobre el pago a Perea de lo que le correspondía como capitán de trincheras, mientras estuviese con la armada de guarda, y dado que nuevamente se le enviaba con la armada que se estaba aderezando en Sevilla "para ir a la provincia de Tierra Firme" a juntarse con la armada que llevó Blasco Núñez Vela, era su voluntad que durante todo este año siguiese disfrutando del salario que tenía en la artillería como capitán de trincheras ${ }^{68}$.

El mismo Perea en carta al rey le comunicaba, a principios de octubre, que "hoy domingo en amaneciendo siete del presente, partimos en buena hora para ir esta jornada de las Indias en seguimiento de Blasco Núñez Vela como Vuestra Majestad me lo envió a mandar, y ruego a Nuestro Señor Dios que me dé también ventura en este viaje, cuales yo llevo los deseos de servir al emperador y rey mi señor, y a Vuestra Majestad en ello”.

La escuadra que en un principio, según vimos, estaba prevista la formasen seis navíos, quedó reducida a cinco, pues la nao de don Pedro de Mendoza, con la que se contaba, vieron que se encontraba "desbaratada y desaparejada” y necesitaban cierto tiempo para aderezarla, y dado que el invierno estaba cerca, no quisieron retrasar la salida de la armada temiendo que algún temporal la retuviese en el puerto ${ }^{69}$. Habían salido de Sanlúcar, como vimos, el 7 de octubre, pero al poco de ir navegando se encontraron con mal tiempo y tuvieron que regresar a la bahía de Cádiz, donde se proveyeron de algunos aparejos que habían echado en falta durante ese mal tiempo que tuvieron, y el miércoles 17 volvieron a salir para reanudar su marcha, "plega a Nuestro Señor de llevarlos y traerlos a todos con próspero viaje ${ }^{70}$.

\footnotetext{
${ }^{67}$ AGI. Indiferente, 1962, L.5, F242-243.

${ }^{68}$ Cédula de 7 de diciembre de 1537. AGI. Indiferente, 423, L.18, F.58v-59r.

${ }^{69}$ AGI. Indiferente, 1092, N.226.

${ }^{70}$ AGI. Indiferente, 1092, N.236.
} 
Durante todo el siguiente año las noticias que tenemos sobre Miguel de Perea son todas relativas a diversos asuntos referentes a pagos a diferentes soldados que habían servido en la armada de Canarias, y a ciertas reclamaciones que se le hacían por lo que había cogido en la nao francesa. El 5 de noviembre de este año 1538 , por cierta reclamación sobre la propiedad de una esclava procedente del botín, sabemos que se encontraba en Málaga, donde daba poderes para que se le representase ante la Corte. La siguiente referencia es de 6 de marzo de 1542 en la que nuevamente da poderes para proseguir el mismo pleito, y esta vez se encuentra en Valladolid, en la Corte. Al parecer en agosto del siguiente año 1543 aún se encuentra en la Corte, al tiempo que Nicolás de Lezo todavía reclamaba que se le pagase lo que había gastado en el mantenimiento de la gente que llevó en su navío para la armada que se había formado en 1536, y que él había pagado por orden del capitán Miguel de Perea, cantidad que se negaban a pagársela alegando que cómo era que reclamaba al cabo de tanto tiempo, y que además según las instrucciones que se dieron, era Perea quien tenía que pagar a la gente.

\section{Su estancia y deceso en Melilla}

A medidos de este siglo XVI el advenimiento de la dinastía Saadita al reino de Fez, cuyo sultán proclamaba en 1549 su intención de no entrar en la capital hasta que no hubiesen sido expulsados los cristianos de Marruecos, hace pensar al monarca en la posibilidad de un ataque a las posesiones de la costa de África, que en general se encontraban mal fortificadas y sin gente preparada para atender a su defensa ${ }^{71}$ [5]. La plaza de Melilla, cuyas últimos intentos de mejorar y adaptar su arcaico sistema de defensa habían sido trazados por Juan Vallejo y el italiano Gabriel Tadino de Martinengo hacía tan solo una veintena de años, ${ }^{72}$ seguía estando necesitada de estas mejoras que, dado lo

\footnotetext{
${ }^{71}$ En marzo de 1549 el veedor Francisco Verdugo, escribía a los regentes diciéndoles que sería conveniente que tuviesen suficientes artilleros, y que mientras se fortificaba la plaza, mandasen algunos de los artilleros de los que tenían a sueldo, "porque en esta tierra el que se quiere llamar artillero es tenido por tal, aunque no sepa nada, y desto ay gran falta en las fronteras". CASTRIES, Hcnry de: Les Sources inédites de L'Historie du Maroc, Archives et Bibliothéques d'Espagne. Tome I, Paris. Ed.: Ernest Leroux, 1921. p.: I-XXVIÜ, p. 200.

${ }^{72}$ En 1525 los ingenieros Tadino y Juan Vallejo por orden de Carlos V realizan en Melilla "un
} 
costoso de las mismas ${ }^{73}$, se iban realizando según apretaban las circunstancias. Ante el temor de un nuevo cerco, se decide enviar a Melilla al capitán Miguel de Perea, experto artillero, entendido también en fortificación [6].

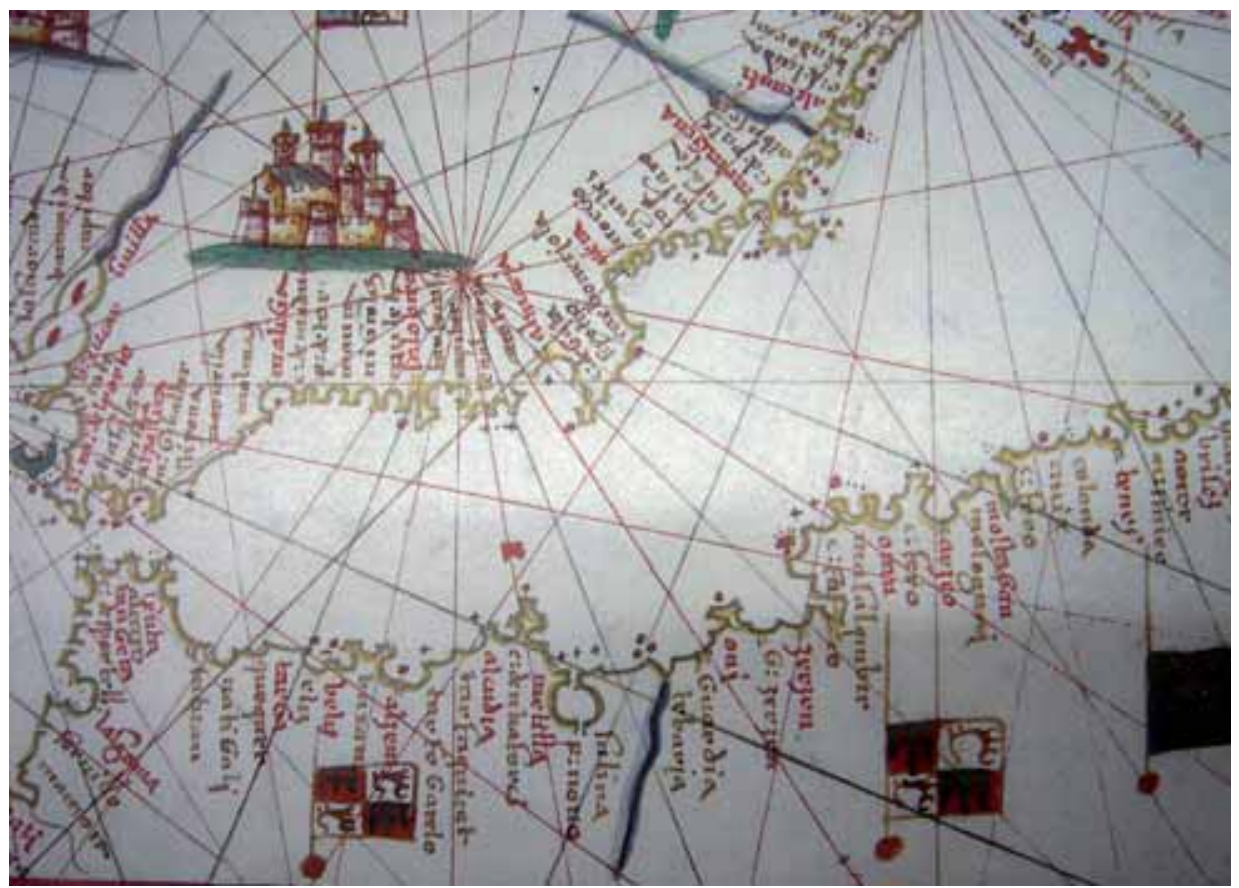

Fig. 5. El mar de Castilla. Portulano de Joan Martines 1570.

atajo de mar a mar hacia la caleta hacia la puerta de la mar por donde más corto y más fuerte se pueda hacer”. Posteriormente Vallejo realiza un nuevo encargo para el frente de Mar en el que destaca el gran cubo conocido como "Hombres del Campo". CASTRO FERNÁNDEZ, José JavierCUADRADO BASAS, África. "Fortificaciones de la corona hispánica en el Mediterráneo durante los siglos XVI y XVII” En Actas IV Congreso de Castellología. Madrid, 2012, p.151.

${ }^{73}$ La escasez de medios provocaba que incluso no se respetasen las dimensiones de las defensas marcadas en las trazas, lo que a veces hacía que éstas fuesen prácticamente inútiles. El torreón de Santi Spiritu, que había trazado Tadino para contrarrestar la altura dominante sobre el Frente de Tierra, se levantará menos sólido y de menor altura, por lo que su misión quedará prácticamente anulada. CÁMARA MUÑOZ, Alicia. "Las fortificaciones de Melilla en el sistema defensivo de la monarquía española. Siglos XVI a XVIII” En Historia de Melilla, Melilla, Ciudad Autónoma, 2005, p.321. 


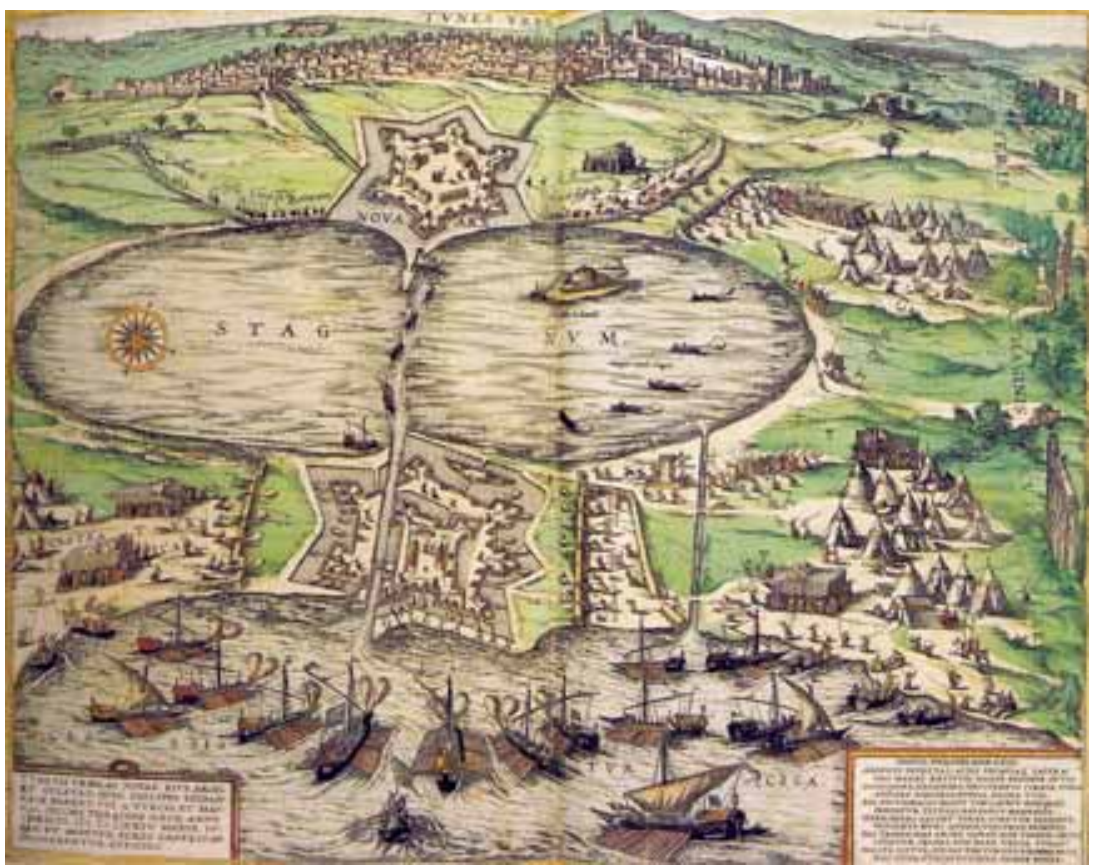

Fig. 6. La plaza de la Goleta en 1535.

Perea llega a Melilla un tormentoso día de marzo de $1549^{74}$ con la misión de finalizar los trabajos de configuración del Primer Recinto ${ }^{75}$, acometiendo enseguida las tareas de "ahondar la cava y teraplenar en donde ay mayor necesidad"76, obra que tienen completada apenas cuatro meses después, "porque no paramos fiestas ni difuntos"77, cuando se suben cuatro piezas de artillería al nuevo muro y terraplenado que habían hecho, continuándose

${ }^{73}$ La escasez de medios provocaba que incluso no se respetasen las dimensiones de las defensas marcadas en las trazas, lo que a veces hacía que éstas fuesen prácticamente inútiles. El torreón de Santi Spiritu, que había trazado Tadino para contrarrestar la altura dominante sobre el Frente de Tierra, se levantará menos sólido y de menor altura, por lo que su misión quedará prácticamente anulada. CÁMARA MUÑOZ, Alicia. "Las fortificaciones de Melilla en el sistema defensivo de la monarquía española. Siglos XVI a XVIII” En Historia de Melilla, Melilla, Ciudad Autónoma, 2005, p.321.

74 CÁMARA. Las fortificaciones de Melilla..., p.325.

${ }^{75}$ Para el estudio del desarrollo de sus fortificaciones, así como del trabajo de los ingenieros militares en Melilla se debe consultar la extensa obra sobre el tema del cronista de la ciudad Antonio BRAVO NIETO.

${ }^{76}$ CASTRIES. Les Sources inédites..., p. 235.

${ }^{77}$ CASTRIES. Les Sources inédites..., p. 366. 
la obra "hasta que se acabe todo lo ques frontera de la villa vieja"78 . [7] Durante el tiempo de su estancia en Melilla, Perea actuará en algún periodo como alcaide interino, alternando este cargo con Juan de Perea ${ }^{79}$ el cual, considerándolo hombre experimentado, le consultará diversos asuntos tocantes a las relaciones con el país vecino ${ }^{80}$, celebrando en una de las ocasiones la consulta en la casa donde se aloja Perea, casa que ha de sostener como a quien corresponde y dado, según decía, que "tengo muy poco, y para poder sostener dos casas, una en Málaga y otra aquy”, solicitaba a los regentes, al menos un par de veces, que le aumentasen su paga mientras se encontrase en Melilla $^{81}$, a lo que accederán aquéllos asignándole una ayuda de costa ${ }^{82}$.

El 27 de abril de 1551 Bartolomé Dorador, lugarteniente del veedor, mandaba un oficio a Juan de Perea notificándole la defunción del capitán Miguel de Perea, y así mismo comunicaba la noticia a la regente María de Austria indicándole que, teniendo que proseguir la obra conforme el parecer de don Bernardino (de Ledesma), se podría evitar el salario especial que cobraba Perea, encargándosela al capitán Francisco Medina, al que estaban esperando, o a Juan de Perea, los cuales, con moderado salario de ayuda de costa, proseguirían la obra. Juan de Perea igualmente comunicaba la noticia del fallecimiento, escribiendo a la regente lo siguiente:

"En veynte y siete de abril fue Dios servido de levar desta presente vida al capitán Miguel de Perea, Dios le lleve a su gloria. Al tiempo questaba

${ }^{78}$ CASTRIES. Les Sources inédites..., p. 325.

79 Con el mismo apellido que Miguel, creemos que no eran parientes, aunque para ello nos basamos tan solo en el comentario que de él hace el capitán: "un hombre muy honrado, aunque no es muy experimentado en las cosas de la guerra, para aquí, para Melilla, es persona que entiende muy bien la guerra de los moros y como se ha de hacer" CASTRIES (1921) p. 345. Juan de Perea ocupó el cargo de teniente de alcaide durante diferentes periodos, entre los años 1547-1554, coincidiendo con las dilatadas ausencias del anciano gobernador Francisco de Medina., hasta la llegada de su sustituto, el joven Francisco de Medina. CASTRIES. Les Sources inédites..., pp. XXIV, 478, 492. Miguel de Perea sería gobernador interino en el periodo 31/10/1549-1/2/1550.

${ }^{80}$ Ante la llegada a Melilla del rey de Vélez de la Gomera buscando refugio y con intención de pasar a España, el teniente de alcaide consulta con Perea y otros funcionarios, reunidos en casa de éste, para que le diesen su parecer si lo enviaba a la península, o lo notificaban a su majestad y esperaban su respuesta. CASTRIES(1921) p. 236.

${ }^{81}$ CASTRIES. Les Sources inédites..., pp. 347, $350,352$.

${ }^{82}$ CASTRIES. Les Sources inédites..., pp. 347, 583. 
al punto de la muerte, hizo escrevir ciertas cartas para SM y VA, y para otras personas, representándoles los servicios que a SM y aVA ha hecho en todo lo que se le ha mandado y ofrecido, y haciendo relación e la proveça que le queda a su muger y a dos hijos y a dos hijas que le quedan, que no les queda sino el favor de SM y de VA. En el entretanto que VA proveyese aca lo que conviene en la fortificación desta ciudad y alla horden que esta mandado por la relación que hizo don Bernardino de Mendoça, hecha será con toda fidelidad y brevedad della" 83 .

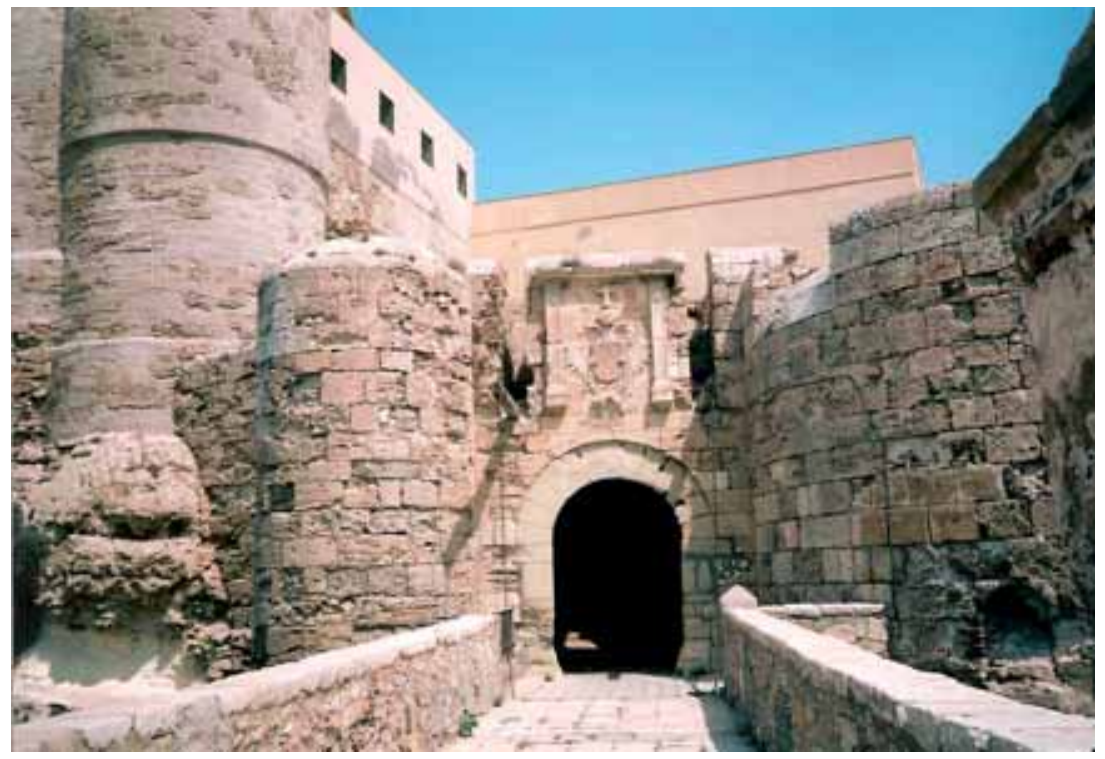

Fig. 7. Puerta de Santiago. Obra de Perea.

Una de las hijas de Perea, Juana de Perea y Acuña, contraería matrimonio con Juan Álvarez de Aguilar, "pagador de la gente de guerra y obras" de la plaza de Melilla, y mayordomo de la artillería ${ }^{84}$. Fueron los padres de Juan

${ }^{83}$ CASTRIES. Les Sources inédites..., p. 581.

${ }^{84}$ Ya figura como pagador en 1571. En 1603 se le hacían merced de 200 ducados de ayuda de costas, como pagador mayordomo de la artillería y tenedor de bastimentos de la gente de guerra. CÁRDENAS PIERA, Emilio. Índice onomástico de la colección de libros de registro del Archivo General Militar de Madrid. Ministerio de Defensa. 2005, p. 28. 
Álvarez de Perea, bautizado en la parroquia de San Miguel Arcángel de Melilla el 6 de febrero de 1559, el cual se casaba en esta plaza en 1605, continuando su descendencia en esta ciudad ${ }^{85}$, donde seguirán desempeñando durante varias generaciones el empleo de pagador, y otros cargos en la milicia.

\section{Fuentes documentales}

Archivo General de Indias (AGI)

Justicia, 1159, N.9 / 1172, N.2, R.4

Patronato, 258, N.1, G.1, R.1

Indiferente, 1961, L2, F. 94v / 1962, L.4, F.155-156; F.161-162; F.162r162v; 162v-163 / 1962, L5, F. 37v-38; F. 51r-51v; 129v-131; 136-137v; 224-225; F.231v-234; F.234v-235; F.237-239; F.242-243 / 422, L17, F.71r71v; F.124v / 423, L18, F.58v-59r / 1092, N.125; N.162; N.204; N.206; N.210; N.214; N.218; N.223; N.225; N.226; N.228; N.231; N.236; N.237; N.241

Archivo General de Simancas (AGS)

Cámara de Castilla (CCA), Diversos (DI) 13, 1/ 13,53

\section{Bibliografía}

APARICIY GARCÍA, José. Continuación del informe sobre los adelantos de la Comisión de la Historia en el Archivo de Simancas. Segunda Parte. Trata de la Artillería e ingenieros en el siglo XVI. Madrid, Imprenta Nacional, 1849.

APARICIY GARCÍA, José. Continuación del informe sobre los adelantos de la Comisión de la Historia en el Archivo de Simancas. Segunda Parte. Trata de las biografías de los ingenieros que existieron en España en el siglo XVI. Madrid, Imprenta del Memorial de Ingenieros, 1851.

BRAVO NIETO, Antonio. “Melilla en el siglo XVI, un ensayo sobre fortificación”. Castillos de España, 94, 1987.

BRAVO NIETO, Antonio. "Poder y arquitectura militar española en el siglo XVI. La orga-

\footnotetext{
${ }^{85}$ Su biznieta Sebastiana Álvarez de Perea, se casaría en Melilla, en diciembre de 1700, con Alonso Durán Viera, natural de Ceuta, capitán que moriría en una salida de esta plaza durante el sitio de 1706, ascendiente del melillense que suscribe.
} 
nización de la frontera mediterránea del sultanato de Fez". En Juan de Herrera y su influencia Universidad de Cantabria. Actas del Simposio-Camargo 14/17 julio, 1992.

BRAVO NIETO, Antonio. "Entre la tradición medieval y el cinquecento. Los ingenieros italianos en Melilla”, en. Architetti e Ingegnieri militari italiani all'estero dal XV al XVIII secolo. Winspeare, Maddalena Paola, Coord, Instituto Italiano dei Castelli, Livorno, 1993-1996.

BRAVO NIETO, Antonio. “Tradición y modernidad en el Renacimiento español: la puerta y capilla de Santiago de Melilla” AKROS, nº 1 , Melilla, 2002.

BRAVO NIETO, Antonio. “Miguel de Perea”. En Diccionario Biográfico Español, Real Academia de la Historia, Madrid, 2009.

CÁMARA MUÑ̃Z, Alicia. "Las fortificaciones de Melilla en el sistema defensivo de la monarquía española. Siglos XVI a XVIII” En Historia de Melilla, Melilla, Ciudad Autónoma, 2005.

CÁMARA MUÑOZ, Alicia. "Las fortificaciones del Emperador Carlos V” En Carlos V: Las Armas y las Letras. Sociedad Estatal para la conmemoración de los centenarios de Felipe II y Carlos V. Granada, 2000.

CÁRDENAS PIERA, Emilio. Índice onomástico de la colección de libros de registro del Archivo General Militar de Madrid. Ministerio de Defensa, 2005.

CASTILLO, Pedro Agustín- SANTIAGO, Miguel. Descripción histórica y geográfica de las Islas Canarias. Las Palmas, 1965.

CASTILlO MATHIEU, Nicolás del. La llave de la Indias. Ediciones El Tiempo, Bogotá, 1981.

CASTRIES, Henry de: Les Sources inédites de L'Historie du Maroc, Archives et Bibliothéques d'Espagne. Tome I, Paris. Ed.: Ernest Leroux, 1921. p.: I-XXVIII.

CASTRO FERNÁNDEZ, José Javier- Cuadrado Basas, África. "Fortificaciones de la corona hispánica en el Mediterráneo durante los siglos XVI y XVII” En Actas IV Congreso de Castellología. Madrid, 2012.

FERNÁNDEZ DURO, Cesáreo. Armada Española. Madrid 1895. Tomo I.

FERNÁNDEZ MARTIN, Luis. "En torno a la batalla de Noáin”, Príncipe de Viana. n 40, Pamplona, 1979.

FERRERAS, Juan. Synopsis historia chronologica de España Parte 13 Madrid 1775.

LÓPEZ MUIÑOS, José. Algunos aspectos de la Ingeniería Militar Española y el Cuerpo Técnico. Imprenta del Ministerio de Defensa. Madrid, 1993.

LUCENA SAlMORAL, Manuel. Piratas, bucaneros, filibusteros y corsarios en América: perros, mendigos y otros malditos del mar. Grijalbo, 1994. 
MARIANA, Juan. Continuación de la Historia de España. Tomo I y XII. Amberes 1766.

MARIÑO, P. Tratados internacionales de España: CarlosV.Vol.2 Madrid 1980.

MARVA, José. “Lista General de los Oficiales del Cuerpo de Ingenieros del Ejército desde el siglo XVI hasta 1910”. Memorial de Ingenieros. Revista XXVIII, 1911.

MIRA CABALLOS, Esteban. La Armada Guardacostas de Andalucía y la defensa de la Carrera de Indias (1521-1550) Muñoz Moya, editor, Sevilla, 1998.

MUGARTEGUI, Juan José. “Un vizcaíno ilustre. El capitán don Juan de Mendiarechaga”. En La villa de Marquina: Monografía histórica. Bilbao 1927.

POLO, Monique. "La vida cotidiana en Melilla en el siglo XVI” Criticón, nº 36. 1986.

RUMEU DE ARMAS, Antonio. Piraterías y ataques navales contra las islas Canarias. CSIC. Instituto Jerónimo Zurita, Tomo I, 1947.

SANDOVAL, Prudencio de. Historia de la vida y hechos del Emperador CarlosV. Primera parte. Pamplona 1634.

SANDOVAL, Prudencio de. Historia de la vida y hechos del Emperador CarlosV. Segunda parte. Amberes 1681.

TOUS MELIÁ, Juan. El cañón Escorpión. De la Torre de Londres al Castillo de Santa Catalina en la isla de La Palma. San Cristóbal de la Laguna 2007.

ZARCO DEL VALLE, A. Resumen histórico del Arma de Ingenieros. Madrid. 1846. 